\title{
Review \\ Focused Ultrasound Stimulation as a Neuromodulatory Tool for Parkinson's Disease: A Scoping Review
}

\author{
Keng Siang Lee ${ }^{1,2,3(\mathbb{D}}$, Benjamin Clennell ${ }^{1,3}$, Tom G. J. Steward $\left.{ }^{1,3}{ }^{(}\right)$, Andriana Gialeli ${ }^{1,2}$, \\ Oscar Cordero-Llana ${ }^{1,2}$ (i) and Daniel J. Whitcomb ${ }^{1,3, *}$ \\ 1 Bristol Medical School, Faculty of Health Sciences, University of Bristol, Bristol BS8 1TH, UK; \\ mrkengsianglee@gmail.com (K.S.L.); ben.clennell@bristol.ac.uk (B.C.); ts7764@bristol.ac.uk (T.G.J.S.) \\ ag15595@bristol.ac.uk (A.G.); oscar.corderollana@bristol.ac.uk (O.C.-L.) \\ 2 Regenerative Medicine Laboratory, School of Clinical Sciences, University of Bristol, Bristol BS8 1TH, UK \\ 3 Institute of Clinical Neurosciences, Bristol Medical School, Translational Health Sciences, University of Bristol, \\ Bristol BS8 1TH, UK \\ * Correspondence: d.j.whitcomb@bristol.ac.uk
}

check for

updates

Citation: Lee, K.S.; Clennell, B.;

Steward, T.G.J.; Gialeli, A.;

Cordero-Llana, O.; Whitcomb, D.J.

Focused Ultrasound Stimulation as a

Neuromodulatory Tool for

Parkinson's Disease: A Scoping

Review. Brain Sci. 2022, 12, 289.

https://doi.org/10.3390/

brainsci12020289

Academic Editor: Monty Silverdale

Received: 13 January 2022

Accepted: 18 February 2022

Published: 19 February 2022

Publisher's Note: MDPI stays neutral with regard to jurisdictional claims in published maps and institutional affiliations.

Copyright: (c) 2022 by the authors. Licensee MDPI, Basel, Switzerland. This article is an open access article distributed under the terms and conditions of the Creative Commons Attribution (CC BY) license (https:// creativecommons.org/licenses/by/ $4.0 /)$.

\begin{abstract}
Non-invasive focused ultrasound stimulation (FUS) is a non-ionising neuromodulatory technique that employs acoustic energy to acutely and reversibly modulate brain activity of deepbrain structures. It is currently being investigated as a potential novel treatment for Parkinson's disease (PD). This scoping review was carried out to map available evidence pertaining to the provision of FUS as a PD neuromodulatory tool. In accordance with the Preferred Reporting Items for Systematic Reviews and Meta-Analysis Extension for Scoping Reviews, a search was applied to Ovid MEDLINE, Embase, Web of Science and Cochrane Central Register of Controlled Trials on 13 January 2022, with no limits applied. In total, 11 studies were included: 8 were from China and 1 each from Belgium, South Korea and Taiwan. All 11 studies were preclinical (6 in vivo, 2 in vitro, 2 mix of in vivo and in vitro and 1 in silico). The preclinical evidence indicates that FUS is safe and has beneficial neuromodulatory effects on motor behaviour in PD. FUS appears to have a therapeutic role in influencing the disease processes of $\mathrm{PD}$, and therefore holds great promise as an attractive and powerful neuromodulatory tool for PD. Though these initial studies are encouraging, further study to understand the underlying cellular and molecular mechanisms is required before FUS can be routinely used in PD.
\end{abstract}

Keywords: neuroscience; neuromodulation; Parkinson's disease; scoping review; ultrasound

\section{Introduction}

Parkinson's disease (PD) is a common and progressive neurodegenerative condition, characterised by the degeneration and death of dopaminergic neurons in the substantia nigra pars compacta $\left(\mathrm{SN}_{\mathrm{pc}}\right)$ and reduced dopamine biosynthesis from surviving neurons [1]. As the disease advances, PD patients can experience motor manifestations typically starting with tremor, progressing to bradykinesia and typical "cogwheel" rigidity, postural instability and gait disorders [2]. These manifestations significantly impact the activities of daily living and health-related quality of life of these patients [2-4]. With the global increase in life expectancy and an ageing population, both the incidence and prevalence of PD have also been rising [5-7], steadily becoming a major public health issue [8].

Deep brain stimulation (DBS) of either the subthalamic nucleus (STN) or internal globus pallidus $\left(\mathrm{GP}_{\mathrm{i}}\right)$ is a well-recognised and established neurosurgical procedure approved for advanced PD refractory to medication. Many hypotheses have been proposed for the mechanisms by which DBS generates improvements in motor symptoms, but prevailing theories have focused on stimulation-induced disruption of pathological brain circuit activity $[9,10]$, which occur at the ionic, protein, cellular and network levels [11]. Although it is effective and in aggregate it is a safe approach [12-15], just like any surgical 
procedure, DBS can be a double-edged sword; it is not free of complications and may even lead to more harm to the patient [16-18]. A consequence of this is strict patient criteria, and thus the number of people that can actually benefit from this treatment is relatively low. Accordingly, the demand for non-invasive alternatives to open stereotactic procedures is significant.

Currently, non-invasive but irreversible neuromodulatory ablative approaches such as stereotactic radiosurgery [19], and even magnetic resonance guided high-intensity focused ultrasound (MRgFUS) for subthalatomy or pallidotomy, are clinically employed for movement disorders [20-24] but are not without complications.

Transcranial magnetic stimulation (TMS) and transcranial current stimulation (TCS) have emerged as the cornerstone of non-invasive modulation of neural activity in particular regions of the brain [25-28]. Although promising, both TMS and TCS are limited by their broad radius of action [29]. This lack of spatial focality is particularly pronounced within the context of neuromodulating deep brain pathways such as the striato-pallidothalamic network or deep structures including the STN and $\mathrm{GP}_{\mathrm{i}}$, which are relevant to PD pathophysiology (Figure 1) [30,31]. TMS and TCS are generally constrained to targeting superficial cortical regions, as their efficacy declines exponentially with depth [30,31]. In contrast, focused ultrasound stimulation (FUS) is a non-invasive and non-ionising technique that employs acoustic energy and can acutely and reversibly modulate deep brain structures with sharp spatial resolution and non-invasive deep penetration [32-34]. FUS therefore holds promise as a powerful neuromodulatory tool for PD.

NORMAL

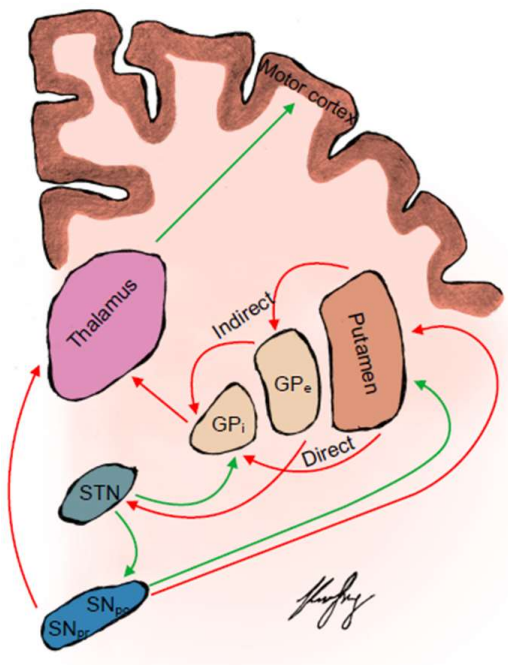

PARKINSON'S DISEASE

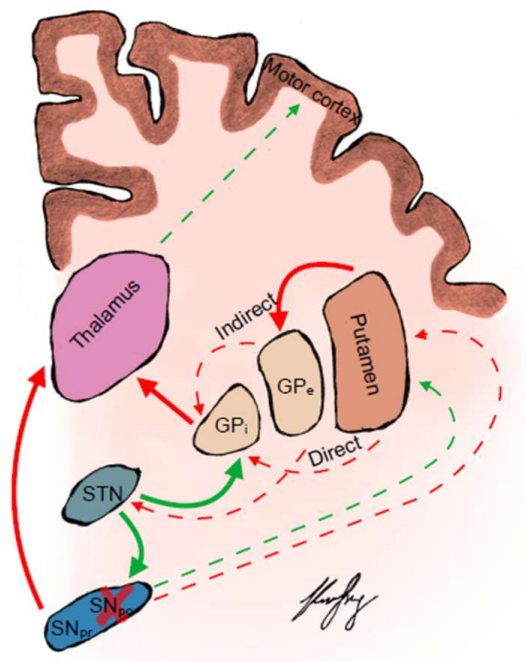

STN ULTRASOUND STIMULATION

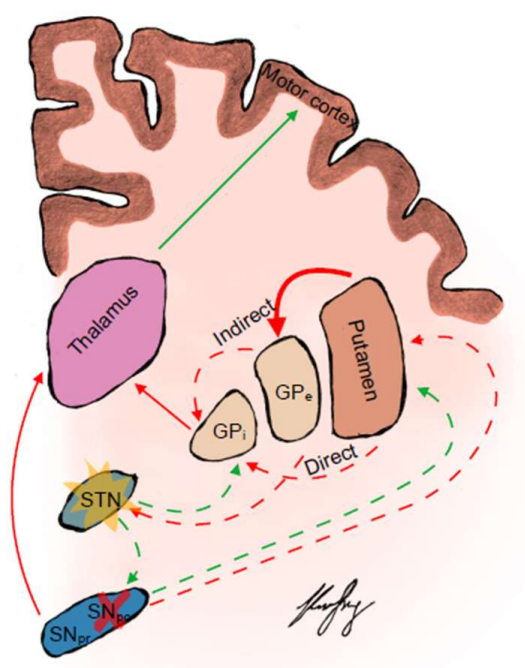

$$
\longrightarrow \text { Excitatory } \longrightarrow \text { Inhibitory } \quad-\quad \rightarrow \text { Decreased effect } \longrightarrow \text { Increased effect }
$$

Figure 1. The basal ganglia circuits in a normal person, PD patient and when they are theoretically modulated by focus ultrasound stimulation of the STN. The direct pathway facilitates while the indirect pathway inhibits movement. The colours represent the excitatory (green) and inhibitory (red) neuronal pathways. The thickness and dottedness of the lines between the regions represent the strength of signalling. The red cross over the SNpc represents degeneration and death of dopaminergic neurons in the SNpc and reduced dopamine biosynthesis from surviving neurons. The yellow star over the STN represents stimulation of the target STN. GPi = globus pallidus internus; GPe = globus pallidus externus; $\mathrm{SNpc}=$ substanstia nigra pars compacta; $\mathrm{SNpr}=$ substanstia nigra pars reticulata; $\mathrm{STN}=$ subthalamic nucleus.

In order to explore the potential of FUS as a neuromodulatory tool in PD, we undertook a scoping review to profile the existing literature. To our knowledge, this is the first scoping 
review of its kind. The overall aims of the scoping review were to collate, map, assess and describe the existing evidence base relating to this topic, in a formal, systematic and transparent way [35]. It is intended that the findings of this review can be used to identify potential gaps in knowledge and contribute to further development of research relating to the field of FUS and PD.

\section{Materials and Methods}

This scoping review was conducted in accordance with the Preferred Reporting Items for Systematic Reviews and Meta-Analysis Extension for Scoping Reviews (PRISMAScR) [36]. Unlike systematic reviews, scoping reviews do not need to have a protocol registered [35]. A scoping review was chosen over a systematic review as emerging evidence relating to the provision of FUS in PD has not been comprehensively reviewed and large variation in reporting exists between studies $[35,37,38]$.

\subsection{Search Strategy}

A search string was developed to identify original studies investigating the role of reversible low-intensity FUS (LIFUS) as a neuromodulatory tool in PD. Current clinically available ablative high-intensity FUS were beyond the scope of this review. The search terms comprised synonyms of two key concepts, namely ultrasound neuromodulation, and Parkinson's disease. The search was applied to the following four electronic databases: Ovid MEDLINE, Embase, Web of Science and Cochrane Central Register of Controlled Trials (CENTRAL). Searches were performed for each database on 13 January 2022. No limits were applied (Supplementary Table S1).

\subsection{Study Selection and Reliability}

Articles were selected for inclusion in the review if they were published in a peerreviewed journal in any language, and addressed the role of FUS as a neuromodulatory tool in PD. All titles and abstracts were screened independently by two reviewers (KSL and BC) against a set of pre-defined eligibility criteria. Potentially eligible studies were selected for full-text analysis. To ensure literature saturation, the reference lists of the included studies were scanned. A summary of the inclusion and exclusion criteria is presented in Supplementary Table S2. Disagreements were resolved by consensus or appeal to a third senior reviewer (DJW). Agreement among the reviewers on study inclusion was evaluated using Cohen's kappa [39].

\subsection{Data Extraction}

A proforma was developed to conduct systematic data extraction with fields relating to (i) study design, (ii) country, (iii) subject models/participants, (iv) intervention assessed, (v) comparators against which FUS interventions are compared, (vi) data collection method and outcome measures and (vii) main findings. Two reviewers independently (KSL and BC) charted data from each eligible article. Any disagreements were resolved through discussion between the two reviewers or further adjudication by a third reviewer (DJW) until consistency was achieved.

\subsection{Outcomes}

Outcome variables were not predefined in this study, due to its exploratory rather than hypothesis-led nature.

\subsection{Synthesis of Results}

A narrative synthesis of data, with descriptive analyses where appropriate, was undertaken to enable the analysis of the relationships within and between studies, as well as assessing gaps in the literature. An analytical framework of quantitative and thematic approach was used to collate various themes that emerged from the existing data. The articles were also coded according to the categories identified in the data charting 
stage. Discrepancies in coding and synthesis of final frequency statistics were adjudicated by discussion.

\section{Results}

\subsection{Characteristics of Inlcuded Studies}

Number of articles screened and selected for inclusion are shown in Figure 2. Using the designated search terms, a total of 373 unique articles were identified and 11 were included in the final dataset [20-22,40-50]. Reliability of study selection between observers was substantial at both the title and abstract screening stage (Cohen's $k=0.94$ ) and the full-text review stage (Cohen's $k=1.00$ ) [39]. Among these 11 articles, 8 were from China and 1 each from Belgium, South Korea and Taiwan. All 11 studies were preclinical [40-50], including 1 computational in silico study [44]. The majority of the primary studies (6 of $11(54.5 \%)$ ) included were published from 2020 onwards, demonstrating the rapid pace at which the field is growing. Table 1 summarises the details and findings of all included studies.

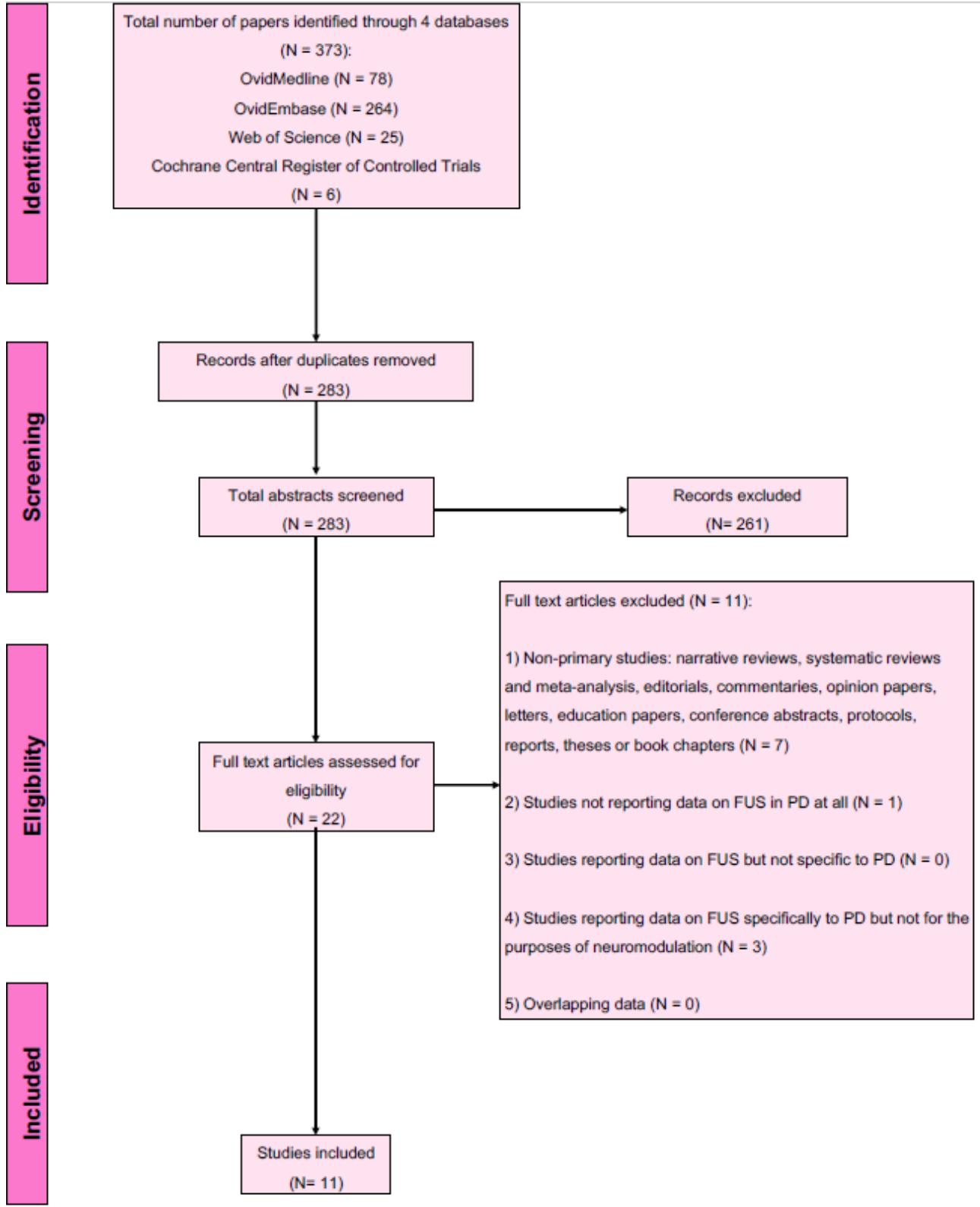

Figure 2. PRISMA flow diagram for studies included and excluded from the scoping review. 
Table 1. Characteristics and summary of findings from the included preclinical studies.

\begin{tabular}{|c|c|c|c|c|c|c|}
\hline Authors and Year & Country & Study Design & $\begin{array}{l}\text { Sample Size, Types of } \\
\text { Subjects/Participants }\end{array}$ & Intervention (Control) & $\begin{array}{c}\text { Outcome } \\
\text { Measures/Indicators }\end{array}$ & $\begin{array}{l}\text { Main Findings Relating to FUS } \\
\text { in PD }\end{array}$ \\
\hline Chen X et al., 2021 & China & In vivo and in vitro & $\begin{array}{c}\mathrm{N}=5 \text { per group. } \\
\text { MPTP-induced } \\
\text { C57BL/6 PD mice } \\
\text { models. MPP+-induced } \\
\text { N2a cells }\end{array}$ & $\begin{array}{l}\text { LIFUS } \\
\text { In vivo: } \\
\text { - } \quad 10 \text { min of ultrasonic } \\
\text { irradiation (every } 24 \mathrm{~h}, \\
\text { - } 5 \text { times) } \\
\text { - } \quad \text { Prequency: } 1 \mathrm{MHz} \\
\text { - } 1 \mathrm{kHz} \\
\text { - } \quad \text { Duty cycle: } 20 \% \text {, for } 10 \mathrm{~min} . \\
\quad \text { Intensity: Grade } 2 \\
\quad 123 \pm 2.781 \pm \text { to } \\
\text { In vitro: } \\
\text { - } \quad \text { Frequency: } 1 \mathrm{MHz} \\
\text { - } \quad \text { Pulse repetition frequency: } \\
\text { - } \quad 1 \mathrm{kHz} \\
\text { - } \quad \text { Inten cycle: } 20 \%, \text { for } 10 \mathrm{~min} \\
\quad(40.5 \pm 1.857 \pm \text { to } \\
\quad 40.3 \pm 0.919 \mathrm{~mW} / \mathrm{cm}^{2} \text {.) }\end{array}$ & $\begin{array}{ll}\text { In vivo measures: } \\
\text { - } & \text { Locomotor behaviour } \\
\text { - } & \text { Proportion of } \mathrm{TH}+ \\
\text { - } & \text { neurons in the } \mathrm{SN}_{\mathrm{pc}} \\
\text { - } & \text { Supronal activity } \\
& \text { MPTP-induced cell } \\
\text { apoptosis } \\
\text { - } \quad \text { Morphological and } \\
\text { pathological changes on } \\
\text { brain sections } \\
\text { In vitro measures: } \\
\text { - } \quad \text { Suppression of } \\
\text { MPP+-induced ROS } \\
\text { generation } \\
\text { Improvement in cell } \\
\text { viability/reduction in } \\
\text { apoptosis }\end{array}$ & $\begin{array}{l}\text { Efficacy: } \\
\text { - In PD mice, LIFUS improved } \\
\text { locomotor function } \\
\text { - } \quad \text { In PD mice, LIFUS } \\
\text { attenuated the central } \\
\text { neurotoxicity of MPTP, } \\
\text { reduced the loss of TH+ } \\
\text { neurons and decreased the } \\
\text { apoptosis in the section of } \\
\text { SN pc } \\
\text { In N2a cells, low-intensity } \\
\text { ultrasound protected against } \\
\text { MPP+-induced neurotoxicity } \\
\text { and mitochondrial } \\
\text { membrane potential damage } \\
\text { Safety: } \\
\text { LIFUS did not cause any } \\
\text { cytotoxicity and tissue } \\
\text { damage as demonstrated by } \\
\text { HE and Nissl staining }\end{array}$ \\
\hline
\end{tabular}


Table 1. Cont.

\begin{tabular}{|c|c|c|c|c|c|c|}
\hline Authors and Year & Country & Study Design & $\begin{array}{l}\text { Sample Size, Types of } \\
\text { Subjects/Participants }\end{array}$ & Intervention (Control) & Outcome Measures/Indicators & $\begin{array}{c}\text { Main Findings Relating to FUS } \\
\text { in PD }\end{array}$ \\
\hline Dong Y et al., 2021 & China & In vivo & $\begin{array}{c}\mathrm{N}=20 \text {. } \\
\text { 6-OHDA-induced } \\
\text { Sprague-Dawley } \\
\text { hemi-PD rat models }\end{array}$ & $\begin{array}{l}\text { LIFUS } \\
\begin{array}{l}\text { - } \\
10 \text { min of ultrasonic } \\
\text { irradiation (total of } \\
200 \text { trials) } \\
\text { - } \quad \text { Frequency: } 500 \mathrm{kHz} \\
\text { - } \quad \text { Pulse repetition frequency: } \\
\text { - } \quad 1 \mathrm{kHz} \\
\quad \text { ISPPA: } 2.6 \mathrm{~W} / \mathrm{cm}^{2}\end{array}\end{array}$ & $\begin{array}{l}\text { - } \quad \text { FA and } \mathrm{T}^{*} \text { values via MRI } \\
\text { scanning } \\
\text { - } \quad \text { Proportion of } \mathrm{TH}+\text { neurons } \\
\text { in the } \mathrm{SN}_{\mathrm{pc}} \\
\text { - } \quad \text { Proportion of } \mathrm{GNDF}+ \\
\text { neurons in the } \mathrm{SN}_{\mathrm{pc}} \\
\text { - } \quad \text { ron content in the } \mathrm{SN}_{\mathrm{pc}}\end{array}$ & $\begin{array}{l}\text { - In hemi-PD rats, LIFUS had } \\
\text { neuroprotective effects and } \\
\text { reduced the damage of } \\
\text { 6-OHDA-induced } \\
\text { neurotoxicity } \\
\text { - } \quad \text { LIFUS increased the } \\
\text { proportion of TH+- and } \\
\text { GDNF+-stained cells in the } \\
\text { SN } \\
\text { - In the 5th and 6th weeks } \\
\text { post stimulation, LIFUS } \\
\text { reduced FA values and } \\
\text { increased T2* values }\end{array}$ \\
\hline $\begin{array}{c}\text { Karmacharya MB } \\
\text { et al., } 2017\end{array}$ & Korea & In vitro & $\begin{array}{l}\mathrm{MPP}^{+} \text {-induced PC12 cell } \\
\text { PD models }\end{array}$ & $\begin{array}{l}\text { Low-intensity ultrasound } \\
\text { - } \quad 10 \text { min of ultrasonic } \\
\text { irradiation (every } 24 \mathrm{~h} \text { ) } \\
\text { - } \quad \text { Frequency: } 1 \mathrm{MHz} \\
\text { - } \quad \text { Intensity: } 30,50, \text { or } \\
\quad 100 \mathrm{~mW} / \mathrm{cm}^{2}\end{array}$ & $\begin{array}{l}\text { - } \quad \text { Suppression of } \\
\mathrm{MPP}^{+} \text {-induced } \alpha \text {-Synuclein } \\
\text { Phosphorylation and } \\
\text { Aggregation } \\
\text { - Suppression of } \\
\mathrm{MPP}^{+} \text {-induced ROS } \\
\text { generation } \\
\text { Attenuation of } \\
\mathrm{MPP}^{+} \text {-induced suppression } \\
\text { of mitochondrial complex I } \\
\text { activity } \\
\text { Suppression of } \\
\text { MPP -induced expression of } \\
\mathrm{CK}^{+} \\
\text {Improvement in cell } \\
\text { viability/reduction in } \\
\text { apoptosis }\end{array}$ & $\begin{array}{l}\text { - In } \mathrm{MPP}^{+} \text {induced PC12 cells, } \\
\text { low intensity ultrasound } \\
\text { attenuated mitochondrial } \\
\text { ROS production and } \\
\text { improved mitochondrial } \\
\text { complex I activity } \\
\text { - Low intensity ultrasound } \\
\text { decreased } \alpha \text {-synuclein } \\
\text { aggregation, levels of } \\
\text { phosphorylated } \alpha \text {-synuclein } \\
\text { and CK2 expression } \\
\text { Low intensity ultrasound } \\
\text { improved cell viability } \\
\text { assessed by MTT and } \\
\text { TUNEL assay, after being } \\
\text { treated with MPP }{ }^{+}\end{array}$ \\
\hline
\end{tabular}


Table 1. Cont.

\begin{tabular}{|c|c|c|c|c|c|c|}
\hline Authors and Year & Country & Study Design & $\begin{array}{l}\text { Sample Size, Types of } \\
\text { Subjects/Participants }\end{array}$ & Intervention (Control) & $\begin{array}{c}\text { Outcome } \\
\text { Measures/Indicators }\end{array}$ & $\begin{array}{c}\text { Main Findings Relating to FUS } \\
\text { in PD }\end{array}$ \\
\hline $\begin{array}{l}\text { Sung CY. et al., } \\
2021\end{array}$ & Taiwan & In vivo & $\begin{array}{c}\mathrm{N}=20 . \\
\text { 6-OHDA-induced } \\
\text { Sprague-Dawley PD rat } \\
\text { models }\end{array}$ & $\begin{array}{l}\text { LIFUS } \\
\begin{array}{ll}\text { - } & 5 \text { min of ultrasonic } \\
& \text { irradiation } \\
\text { - } & \text { Frequency: } 1 \mathrm{MHz} \\
\text { - } & \text { Pulse repetition frequency: } \\
& 1 \mathrm{~Hz} \\
\text { - } & \text { Duty cycle: } 5 \% \\
\text { - } & \text { Burst length: } 5 \mathrm{~ms} \\
\text { - } & \text { ISPTA: } 528 \mathrm{~mW} / \mathrm{cm}^{2}\end{array}\end{array}$ & $\begin{array}{ll}\text { - } & \text { Locomotor behaviour } \\
\text { Proportion of } \mathrm{TH}+ \\
\text { neurons in the } \mathrm{SN}_{\mathrm{pc}} \\
\text { Proportion of } \mathrm{GNDF} \\
\text { neurons in the } \mathrm{SN}_{\mathrm{pc}} \\
\text { Proportion of } \mathrm{BNDF} \\
\text { neurons in the } \mathrm{SN}_{\mathrm{pc}} \\
\text { - } \\
\text { Reduction of } \\
\text { neuroinflammation }\end{array}$ & $\begin{array}{l}\text { - In PD rats, LIFUS improved } \\
\text { locomotor function } \\
\text { In PD rats, LIFUS increased } \\
\text { the proportion of TH+ } \\
\text { neurons in the striatum and } \\
\text { SNPC } \\
\text { - } \quad \text { In PD rats, LIFUS increased } \\
\text { the levels of GDNF in the } \\
\text { SN } \text { pc }_{\text {but not BDNF levels. }} \\
\text { LIFUS attenuated } \\
\text { LCN2-induced } \\
\text { neuroinflammation }\end{array}$ \\
\hline $\begin{array}{l}\text { Tarnaud T et al., } \\
2019\end{array}$ & Belgium & $\begin{array}{l}\text { Computational } \\
\text { modelling study }\end{array}$ & $\begin{array}{l}\text { A computational model } \\
\text { for ultrasonic } \\
\text { stimulation of the STN is } \\
\text { created by combining the } \\
\text { Otsuka model with the } \\
\text { bilayer sonophore model }\end{array}$ & $\begin{array}{l}\text { LIFUS } \\
\begin{array}{l}\text { - Variable parameters } \\
\text { explored }\end{array}\end{array}$ & - $\quad$ Parameter optimisation & $\begin{array}{l}\text { - In the STN, low intensities } \\
\text { result in repetitive firing, } \\
\text { while higher intensities } \\
\text { result in silences } \\
\text { Pulsed ultrasonic } \\
\text { stimulation results in a } \\
\text { shorter saturation latency } \\
\text { and can modulate } \\
\text { spiking rates }\end{array}$ \\
\hline
\end{tabular}


Table 1. Cont.

\begin{tabular}{|c|c|c|c|c|c|c|}
\hline Authors and Year & Country & Study Design & $\begin{array}{l}\text { Sample Size, Types of } \\
\text { Subjects/Participants }\end{array}$ & Intervention (Control) & $\begin{array}{c}\text { Outcome } \\
\text { Measures/Indicators }\end{array}$ & $\begin{array}{l}\text { Main Findings Relating to FUS } \\
\text { in PD }\end{array}$ \\
\hline Wang Z et al., 2020 & China & In vivo & $\begin{array}{c}\mathrm{N}=11 . \text { MPTP-induced } \\
\text { C57BL } / 6 \text { PD mice } \\
\text { models }\end{array}$ & 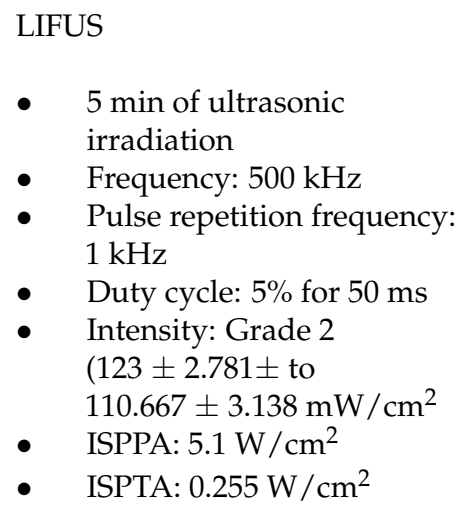 & $\begin{array}{l}\text { - Local field potentials in } \\
\text { the motor cortex (M1) }\end{array}$ & $\begin{array}{l}\text { In PD mice, LIFUS can } \\
\text { influence important } \\
\text { biomarkers of PD in M1. } \\
\text { In the M1, LIFUS reduced } \\
\text { the mean power intensity in } \\
\text { the beta band } \\
\text { In the M1, LIFUS reduced } \\
\text { the PAC strength of both } \\
\text { beta/high gamma and } \\
\text { beta/ripple bands }\end{array}$ \\
\hline Xu T et al., 2020 & China & In vivo and in vitro & $\begin{array}{c}\mathrm{N}=12 \text { per group. } \\
\text { MPTP-induced C57BL/ } 6 \\
\text { PD mice models and } \\
\text { PC12 cells }\end{array}$ & 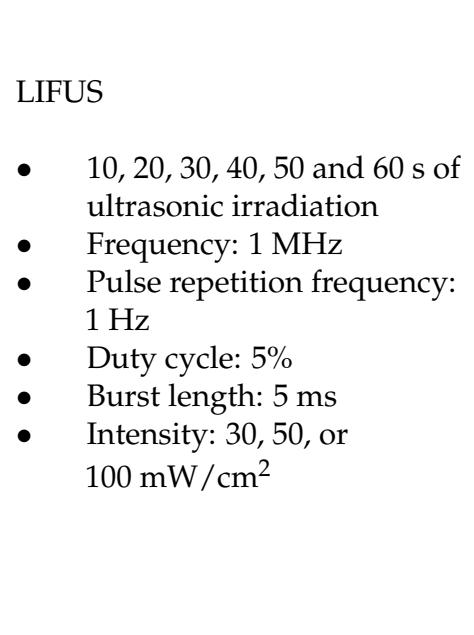 & $\begin{array}{l}\text { In vivo measures: } \\
\text { Locomotor behavior } \\
\text { - } \quad \text { Locomotor behaviour } \\
\text { - } \quad \text { Dopamine content in the } \\
\text { - } \quad \mathrm{SN}_{\mathrm{pc}} \\
\text { Proportion of } \mathrm{TH}+ \\
\text { - } \quad \text { Meurons in the } \mathrm{SN}_{\mathrm{pc}} \\
\text { - } \quad \text { Morphological and } \\
\text { pathological changes on } \\
\text { brain sections } \\
\text { In vitro measures: } \\
\text { - } \quad \text { Dopamine release from } \\
\quad \text { PC12 cells }\end{array}$ & $\begin{array}{l}\text { Efficacy } \\
\text { - In PC12 cells, low-intensity } \\
\text { ultrasound enhanced DA } \\
\text { release } \\
\text { - } \quad \text { In PD mice, 10-day LIFUS } \\
\text { enhanced DA content in the } \\
\text { striatum } \\
\text { - } \quad \text { In PD mice, LIFUS restored } \\
\text { locomotor activity and } \\
\text { enhanced the number of TH+ } \\
\text { neurons in the SN } \mathrm{Pc}_{\mathrm{pc}} \\
\text { Safety } \\
\text { - } \quad \text { LIFUS did not cause any } \\
\text { cytotoxicity and tissue } \\
\text { damage as demonstrated by } \\
\text { HE and Nissl staining }\end{array}$ \\
\hline
\end{tabular}


Table 1. Cont.

\begin{tabular}{|c|c|c|c|c|c|c|}
\hline Authors and Year & Country & Study Design & $\begin{array}{l}\text { Sample Size, Types of } \\
\text { Subjects/Participants }\end{array}$ & Intervention (Control) & $\begin{array}{c}\text { Outcome } \\
\text { Measures/Indicators }\end{array}$ & $\begin{array}{c}\text { Main Findings Relating to FUS } \\
\text { in PD }\end{array}$ \\
\hline Yuan Y et al. 2020 & China & In vivo & $\begin{array}{l}\mathrm{N}=8 \text { per group. } \\
\text { MPTP-induced C57BL/6 } \\
\text { PD mice models }\end{array}$ & 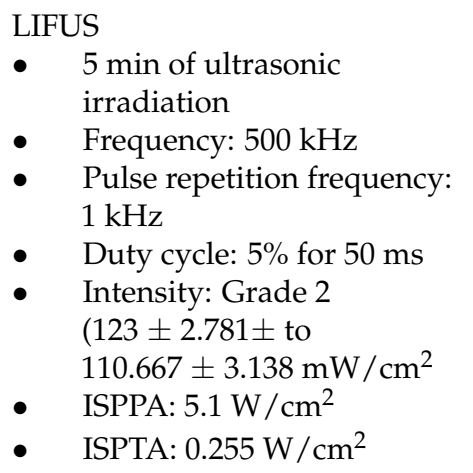 & - $\quad$ Locomotor behaviour & $\begin{array}{l}\text { - In PD mice, LIFUS improved } \\
\text { the locomotor behaviour } \\
\text { - The treatment effect } \\
\text { improved with increased } \\
\text { LIFUS duration }\end{array}$ \\
\hline Zhao L et al., 2017 & China & In vitro & $\begin{array}{l}\text { PC12 cells exposed to } \\
\mathrm{MPP}^{+} \text {-induced } \\
\text { neurotoxicity }\end{array}$ & $\begin{array}{l}\text { Low-intensity ultrasound } \\
\text { - } \quad 10 \text { min of ultrasonic } \\
\text { irradiation } \\
\text { - } \quad \text { Frequency: } 1 \mathrm{MHz} \\
\text { - } \quad \text { Pulse repetition frequency: } \\
\quad 100 \mathrm{~Hz} \\
\text { - } \quad \text { Duty cycle: } 20 \% \text { for } 10 \mathrm{~min} \\
\text { - } \quad \text { ISPTA: } 50 \mathrm{~mW} / \mathrm{cm}^{2}\end{array}$ & $\begin{array}{ll}\text { - } & \text { Suppression of } \\
\mathrm{MPP}^{+} \text {-induced ROS } \\
\text { generation } \\
\text { Attenuation of } \\
\mathrm{MPP}^{+} \text {-induced } \\
\text { suppression of } \\
\text { mitochondrial complex I } \\
\text { activity } \\
\text { - Improvement in cell } \\
\text { viability/reduction in } \\
\text { apoptosis }\end{array}$ & $\begin{array}{l}\text { In PC12 cells, low-intensity } \\
\text { ultrasound inhibited } \\
\text { MPP }^{+} \text {-induced neurotoxicity } \\
\text { and mitochondrial } \\
\text { dysfunction } \\
\text { Low-intensity ultrasound } \\
\text { decreased MPP }{ }^{+} \text {-induced } \\
\text { oxidative stress by } \\
\text { modulating antioxidant } \\
\text { proteins, including } \\
\text { thioredoxin-1 and haem } \\
\text { oxygenase-1, and prevented } \\
\text { neurocytotoxicity via the } \\
\text { phosphoinositide 3-kinase } \\
\text { (PI3K)-Akt and ERK1/2 } \\
\text { pathways. } \\
\text { This neuroprotective effect } \\
\text { was attributed to the } \\
\text { activation of K2P channels } \\
\text { and stretch-activated } \\
\text { ion channels }\end{array}$ \\
\hline
\end{tabular}


Table 1. Cont.

\begin{tabular}{|c|c|c|c|c|c|c|}
\hline Authors and Year & Country & Study Design & $\begin{array}{c}\text { Sample Size, Types of } \\
\text { Subjects/Participants }\end{array}$ & Intervention (Control) & $\begin{array}{c}\text { Outcome } \\
\text { Measures/Indicators }\end{array}$ & $\begin{array}{c}\text { Main Findings Relating to FUS } \\
\text { in PD }\end{array}$ \\
\hline $\begin{array}{l}\text { Zhou H et al., } \\
\text { 2019a }\end{array}$ & China & In vivo & $\begin{array}{c}\mathrm{N}=8 . \mathrm{MPTP} \text { induced } \\
\text { C57BL/6 PD mice } \\
\text { models }\end{array}$ & $\begin{array}{ll}\text { LIFUS } \\
\text { - } \quad 30 \text { min of ultrasonic } \\
\text { - } \quad \text { irradiation daily } \\
\text { - } \quad \text { Prequency: } 3.8 \mathrm{MHz} \\
\text { - } \quad 1 \mathrm{kHz} \\
\text { - } \quad \text { Duty cycle: } 50 \% \text { for } 10 \mathrm{~min} \\
\quad \text { ISPTA: } 430 \mathrm{~mW} / \mathrm{cm}^{2}\end{array}$ & $\begin{array}{ll}\text { - } & \text { Locomotor behaviour } \\
\text { - } & \text { Proportion of } \mathrm{TH}+ \\
\text { - } & \text { Neurons in the } \mathrm{SN}_{\mathrm{pc}} \\
& \text { Suppression of } \\
\text { MPTP-induced cell } \\
\text { apoptosis/reduction of } \\
\text { antioxidant enzyme } \\
\text { activity } \\
\text { Morphological and } \\
\text { pathological changes on } \\
\text { brain sections }\end{array}$ & $\begin{array}{l}\text { Efficacy } \\
\text { - } \quad \text { In PD mice, LIFUS of the } \\
\text { STN or GP } \text { improved motor }_{\text {im }} \\
\text { behaviour } \\
\text { LIFUS improved neuronal } \\
\text { activity } \\
\text { LIFUS stimulation of either } \\
\text { STN or GP } \text { protected against }_{\text {MPTP-induced neurotoxicity }} \\
\text { in dopaminergic neurons by } \\
\text { downregulating Bax, } \\
\text { upregulating Bcl-2 and } \\
\text { blocking cytochrome c } \\
\text { release from mitochondria } \\
\text { and reducing } \\
\text { cleaved-caspase } 3 \text { activity in } \\
\text { the SN } \text { pc }^{-} \\
\text {Safety } \\
\text { LIFUS did not cause any } \\
\text { cytotoxicity and tissue } \\
\text { damage as demonstrated by } \\
\text { HE and Nissl staining }\end{array}$ \\
\hline
\end{tabular}


Table 1. Cont.

\begin{tabular}{|c|c|c|c|c|c|c|}
\hline Authors and Year & Country & Study Design & $\begin{array}{c}\text { Sample Size, Types of } \\
\text { Subjects/Participants }\end{array}$ & Intervention (Control) & $\begin{array}{c}\text { Outcome } \\
\text { Measures/Indicators }\end{array}$ & $\begin{array}{c}\text { Main Findings Relating to FUS } \\
\text { in PD }\end{array}$ \\
\hline $\begin{array}{l}\text { Zhou H et al., } \\
\text { 2019b }\end{array}$ & China & In vivo & $\begin{array}{c}\mathrm{N}=8 . \mathrm{MPTP} \text {-induced } \\
\text { C57BL/6 PD mice } \\
\text { models }\end{array}$ & $\begin{array}{ll}\text { LIFUS } \\
\text { - } \quad 40 \text { min of ultrasonic } \\
\text { - } \quad \text { Frradiation daily } \\
\text { - } \quad \text { Pulse repetition frequency: } \\
\quad 100 \mathrm{~Hz} \\
\text { - } \quad \text { Duty cycle: } 10 \% \\
\text { - } \quad \text { ISPPA: } 760 \mathrm{~mW} / \mathrm{cm}^{2}\end{array}$ & $\begin{array}{ll}\text { - } & \text { Locomotor behaviour } \\
\text { - Suppression of } \\
\text { MPTP-induced cell } \\
\text { apoptosis/reduction of } \\
\text { antioxidant enzyme } \\
\text { activity } \\
\text { - } \quad \text { Neuronal activity } \\
\text { Morphological and } \\
\text { pathological changes on } \\
\text { brain sections }\end{array}$ & $\begin{array}{l}\text { Efficacy } \\
\text { - } \quad \text { In PD mice, LIFUS improved } \\
\text { locomotor activity } \\
\text { - } \quad \text { LIFUS increased striatal total } \\
\text { superoxide dismutase and } \\
\text { glutathione peroxidase, } \\
\text { important for the protection } \\
\text { against MPTP-induced } \\
\text { toxicity } \\
\text { Safety } \\
\text { - LIFUS did not cause any } \\
\text { cytotoxicity and tissue } \\
\text { damage as demonstrated by } \\
\text { HE and Nissl staining }\end{array}$ \\
\hline
\end{tabular}

6-OHDA = 6-hydroxydopamine; BDNF = Brain-derived neurotrophic factor; DBS = Deep brain stimulation; FA = Fractional anisotropy; GDNF = Glial cell line-derived neurotrophic factor; $\mathrm{GPi}=$ Globus pallidus internus; $\mathrm{HE}=$ Haematoxylin and eosin; ISPPA = Spatial peak and pulse-average intensity; ISPTA = Spatial peak and temporal average intensity; LDH = Lactate dehydrogenase; LFP = Local field potential; LIFUS = Low-intensity focused ultrasound; MPP ${ }^{+}=1$-methyl-4-phenylpyridinium; MPTP = 1-methyl-4-phenyl-1, 23,6tetrahydropyridine; MTT = 3-(4,5-dimethylthiazol-2-yl)-2,5-diphenyltetrazolium bromide; $\mathrm{PD}=$ Parkinson's disease; ROS = Reactive oxygen species; SNpc = Substantia nigra pars compacta; STN = Subthalamic nucleus; TH = Tyrosine hydroxylase; TUNEL = Terminal deoxynucleotidyl transferase dUTP nick end labelling. 


\subsection{Outcome Measures}

An extensive range of neuromodulatory outcomes were identified (Table 1). These outcome measures were considered and categorised into two main areas: those relevant to in vitro models and those relevant to in vivo models. The most frequently investigated outcome variable employed in in vitro studies were improvement in cell viability/reduction in apoptosis $(n=3)$, suppression of 1-methyl-4-phenylpyridinium ion $\left(\mathrm{MPP}^{+}\right)$-induced reactive oxygen species (ROS) generation $(n=3)$, attenuation of $\mathrm{MPP}^{+}$-induced suppression of mitochondrial complex I activity $(n=2)$, suppression of $\mathrm{MPP}^{+}$-induced expression of casein kinase 2 (CK2) that mediates ROS-dependent $\alpha$-synuclein aggregation $(n=1)$ and finally dopamine release $(n=1)$. For the in vivo studies, the most frequently studied outcome variable to evaluate the effectiveness of FUS was locomotor behaviour $(n=6)$ assessed using a battery of tests such as the rotarod and pole and open field forced swimming tests. The next common measures to ascertain therapeutic effects included the proportion of tyrosine hydroxylase (TH) enzyme $(n=5)$ and glial cell line-derived neurotrophic factor (GDNF)-positive neurons in the SNpc $(n=2)$. Suppression of 1-methyl-4-phenyl1,2,3,6-tetrahydropyridine (MPTP)-induced cell apoptosis/reduction of antioxidant enzyme activity $(n=2)$ and neuronal activity using c-Fos as a surrogate was also investigated $(n=2)$. Other investigated outcomes included the reduction in iron staining in the SNpc $(n=1)$, proportion of brain-derived neurotrophic factor (BDNF)-positive neurons in the SNpc $(n=1)$, dopamine content in the SNpc $(n=1)$ and fractional anisotropy (FA) and T2* values via magnetic resonance imaging (MRI) scanning $(n=1)$ and local field potentials in the motor cortex $(n=1)$. Safety outcomes included the lack of haemorrhage and morphological changes on brain sections $(n=4)$, typically ascertained by haematoxylin and eosin $(\mathrm{HE})$ and Nissl staining.

\subsection{Trends and Findings from In Vitro Preclinical Studies}

Differentiated pheochromocytoma (PC12) and N2a cells exposed to $\mathrm{MPP}^{+}$-induced neuronal toxicity were the most commonly studied models of PD in vitro. Karmacharya showed that in $\mathrm{MPP}^{+}$treated PC12 cells, low-intensity ultrasound attenuated mitochondrial ROS production and reversed the inhibition of mitochondrial complex I activity by $\mathrm{MPP}^{+}$[42]. When cells treated with 400 or $800 \mu \mathrm{M} \mathrm{MPP}^{+}$were stimulated with 30, 50 and $100 \mathrm{~mW} / \mathrm{cm}^{2}$ ultrasound for $10 \mathrm{~min}$, the mitochondrial ROS production was decreased as compared to non-stimulated group as demonstrated by a reduction in the MitoSOX Red intensity, which was found to be stimulation intensity dependent [42].

Mitochondrial integrity is tightly regulated by the balance between pro-apoptotic Bax and anti-apoptotic Bcl-2 [51-58]. In the context of MPTP and $\mathrm{MPP}^{+}$neurotoxic damage, Bax downregulation attenuates DA neuron apoptosis [1,53,59], whereas Bcl-2 upregulation has neuroprotective effects against the depletion of striatal dopamine $[53,59,60]$. Zhao and colleagues showed that low-intensity ultrasound pre-treatment increased the Bcl-2/Bax ratio, prevented Cytochrome $C$ release and suppressed cleaved-caspase 3 activity that would all be present after $\mathrm{MPP}^{+}$exposure [48]. Additionally, low-intensity ultrasound attenuated $\mathrm{MPP}^{+}$-induced ROS accumulation and oxidative stress in PC12 cells by modulating the expression of antioxidant proteins haem oxygenase-1 (HO-1) and thioredoxin-1 (Trx-1), and improved mitochondrial membrane potential in both PC12 cells [48] and in N2a cells [40].

Low-intensity ultrasound improved cell viability in both PC12 and N2a cells after being treated with $\mathrm{MPP}^{+}$as assessed by lactate dehydrogenase (LDH), MTT and TUNEL assays [42,48]. Pre-treatment with low-intensity ultrasound suppressed the MPP+-induced increase in the level of caspase-9 cleavage products [48], suggesting that low-intensity ultrasound can modulate the mitochondrial apoptotic pathway, but not endoplasmic reticulum stress-induced apoptotic pathway. Importantly, low-intensity ultrasound decreased $\mathrm{MPP}^{+}$. induced $\alpha$-synuclein aggregation, levels of phosphorylated $\alpha$-synuclein and expression of CK2 [42], which constitutively phosphorylates $\alpha$-synuclein at S129 [61,62]. 
These findings suggest that low-intensity ultrasound can help to maintain integrity and function of challenged mitochondria. Together, this indicates that low-intensity ultrasound inhibited $\mathrm{MPP}^{+}$-induced mitochondrial dysfunction and apoptosis.

\subsection{Trends and Findings from In Vivo Preclinical Studies}

With a steady increase in the number of publications relating to research of FUS in PD, contemporary animal models were most often mouse and rat species. No primate, dog or pig species were used during the study period. Induction of a PD phenotype was typically by intraperitoneal injection of MPTP in C57BL/ 6 mice or by intracranial injection of 6-hydroxydopamine (6-OHDA) in Sprague-Dawley rats.

In the study by Zhou et al., they observed that LIFUS (30 min daily, for 12 days) targeting either the STN or GPi, upregulated Bcl-2, downregulated Bax and inhibited increments in protein levels of both Cytochrome $C$ and cleaved-caspase 3 , thereby reversing the changes of MPTP exposure in C57BL/6 mice [49]. These findings are in agreement with the in vitro findings by Zhao et al. in PC12 cells [48].

$\mathrm{TH}$ is the rate-limiting enzyme responsible for catalysing the conversion of the amino acid L-tyrosine to L-3,4-dihydroxyphenylalanine (L-DOPA), which is eventually transformed to dopamine [63]. Multiple studies showed that LIFUS ameliorated the reduction of TH in the SNpc and striatum induced by MPTP or 6-OHDA administration as detected by immunohistochemical analyses, demonstrating the restorative effects of LIFUS on the nigrostriatal pathway $[40,41,43,46]$. Importantly, $\mathrm{Xu}$ et al. showed that this rise in $\mathrm{TH}$ levels was accompanied by an increase in striatal dopamine levels as measured by isocratic elution and electrochemical detection [46].

In 6-OHDA-induced Sprague-Dawley hemi-lesioned-PD rat models, LIFUS to the striatum increased the levels of GDNF in the SNpc but not in the striatum $[41,43]$. GDNF has potent neuroprotective and neurorestorative effects particularly, but not exclusively, on dopaminergic neurons in animal models of PD [64]. The mechanism is still unclear, but a plausible explanation for the rise in GDNF levels with low-intensity transcranial ultrasound stimulation (LITUS) could be that LITUS disrupted the BBB acutely and promoted exogenous GDNF to enter the brain [65-68], or that LITUS resulted in glial activation, and the increase in astroglia promoted increased endogenous GDNF. Importantly, LIFUS of either the STN or GPi restored motor behaviour and coordination damaged by MPTP or 6-OHDA, as assessed by the rotarod and pole tests, in both PD mice [40,47,49,50] and rat models [43]. This treatment effect continued to improve with increased LIFUS duration $[40,47,49,50]$.

To evaluate the safety of LIFUS in vivo, all studies had employed the use of HE staining to assess the presence of haemorrhage or tissue damage and Nissl staining to visualise neurons in brain sections $[40,46,48-50]$. All studies reported the absence of haemorrhage, or cytotoxic damage with normal neuronal density throughout the brain $[40,46,48-50]$.

\section{Discussion}

\subsection{Summary of Findings}

This work represents the first attempt to comprehensively review the available preclinical and clinical evidence pertaining to the function of FUS as a non-invasive and reversible treatment for PD worldwide, during established irreversible neuromodulatory stereotactive procedures, such as DBS, and ablative approaches, such as stereotactic radiosurgery and MRgFUS.

Our review demonstrates preclinical evidence of the safety and efficacy of FUS neuromodulation, but also highlights the paucity of in vitro evidence relating to its mechanisms of action.

\subsection{Implications of Findings: Association and Causality}

A causal relationship between FUS and neuromodulation of PD is tenable. Based on the Bradford Hill criteria [69], this may be supported by the strength and dose-dependent association reported in in vitro and in vivo preclinical studies [20-22,40-50,70-74]. The 
literature has consistently proven that FUS is capable of eliciting various behavioural responses in various PD models [40,43,47,49,50,72-75], inducing protein expression changes in GDNF [41,43], TH [40,41,43,46] and dopamine levels [46] in the SNpc, which are implicated in the disease pathology of PD. Indeed, the treatment effect continued to improve with increased LIFUS duration, even suggesting a dose-response relationship $[40,47,49,50]$.

These phenomena are reinforced further by the biological plausibility of a mechanical bioeffect [76]. Although FUS is known to have a thermal effect, with the parameters used for neuromodulation [77] this is unlikely to play a major role. Generally, low-intensity protocols are employed $(<20 \mathrm{~W} / \mathrm{cm} 2)$ for the purpose of neuromodulation, which is within Food and Drug Administration limits [70,73,78]. At such intensities, the accompanying temperature rise is deemed too miniscule $\left(<0.1^{\circ} \mathrm{C}\right)$ to potentiate neuromodulation [79], or even cause tangible thermal damage [70,72]. Studies have alternatively suggested that the most probable mechanism of FUS action is through acoustic radiation force (ARF) generation, which promotes neuronal membrane strain, consequently modulating its capacitance and its embedded mechanosensitive channel proteins [80-82]. Consistent with this notion, particular channels appear to be directly modulated by FUS include voltage-gated sodium, potassium and calcium channels [70,83], and channels of the Piezo family [84]. Additionally, there are speculations that LITUS resulted in glial activation, and the increase in astroglia promoted increased endogenous GDNF [65-68,85,86]. There is compelling evidence that the neuromodulatory effects elicited by LIFUS in vivo are mediated additionally by non-neuronal mechanisms such as glia-neuron interaction in the mammalian brain. Astrocytes, with their long peripheral processes, have intimate spatial relationships with presynaptic and postsynaptic synapses of neighbouring neurons (also known as the tripartite synapse) [87-89]. Dysregulation of the astrocyte-dopaminergic neuron interaction has a role in the pathophysiology of PD [90]. It is also well-established that the $\mathrm{Ca}^{2+}$-dependent release of glutamate from astrocytes stimulate neuronal NMDA receptors (NMDARs), modulating their synaptic activity [91-93]. Oh and colleagues reported that this FUS-induced neuromodulation is initiated by the opening of TRPA1 $\mathrm{Ca}^{2+}$ channels in astrocytes, which are pressure sensitive. This astrocytic influx of $\mathrm{Ca}^{2+}$ entry prompts the release of gliotransmitters such as glutamate through Best1 channels, which eventually activates the NMDAR of neurons in the vicinity to elicit action potential firing [91]. Interestingly, Blackmore et al. corroborated these findings in a recent study that showed FUS restored long-term potentiation and memory in senescent mice. Specifically, they demonstrated that FUS significantly raised levels of TRPA1 levels in synaptosomal hippocampal fractions compared with sham treatments [94]. This increase, reflected by the changes observed for NMDAR subunits in these fractions, suggests that ultrasoundmediated astrocytic glutamate release is a likely mechanism by which FUS led to the observed improvements in senescent mice, which may also explain the improvements in locomotor behaviour as seen in PD models [94].

\subsection{Implication on the Direction of Future Research}

FUS holds promise as a powerful neuromodulatory tool for PD and is hence attractive, and studies have investigated this in a multitude of ways. Consistent reporting of the neuromodulatory effects of FUS can be facilitated by an agreed minimum set of indicators to be reported, for example, changes in the expression of neuroprotective proteins for in vitro studies. Consistent reporting of these outcomes across future studies will enhance the validity of evidence syntheses [95]. By virtue of the fact that preclinical studies such as those we have highlighted rely on models of PD pathology that might not completely reflect disease mechanisms in humans, it is particularly important that future studies assessing the neuromodulatory effects of FUS for PD meet criteria spanning across the cellular, molecular and behavioural levels. This will help build confidence in the novel intervention being of relevance to the human disease state. Additionally, preclinical animal models typically include a behavioural component to assess the motor deficits characteristic of PD. These usually include locomotor deficits evident in various motor behaviour and 
coordination assays. There is a general consensus that the animal models offer compelling similarity in functional deficits to those found in humans [96]. Therefore, an important outcome measure for any future intervention studies would likely include demonstration of improvements in these key movement metrics. Table 2 outlines a proposed checklist for the outcome measures to directly assess the neuromodulatory effects of FUS for PD as a starting point. This checklist is intentionally generic, representing a minimum set of critically important outcomes to report in all studies evaluating the introduction and evaluation of FUS neuromodulation relevant to PD and should not restrict investigators in their reporting of additional relevant outcomes. In future, this could be further refined by a Delphi consensus of various stakeholders-scientists, electrophysiologists, neurologists and neurosurgeons.

Table 2. A proposed checklist for the outcome measures to directly assess the neuromodulatory effects of FUS for PD.

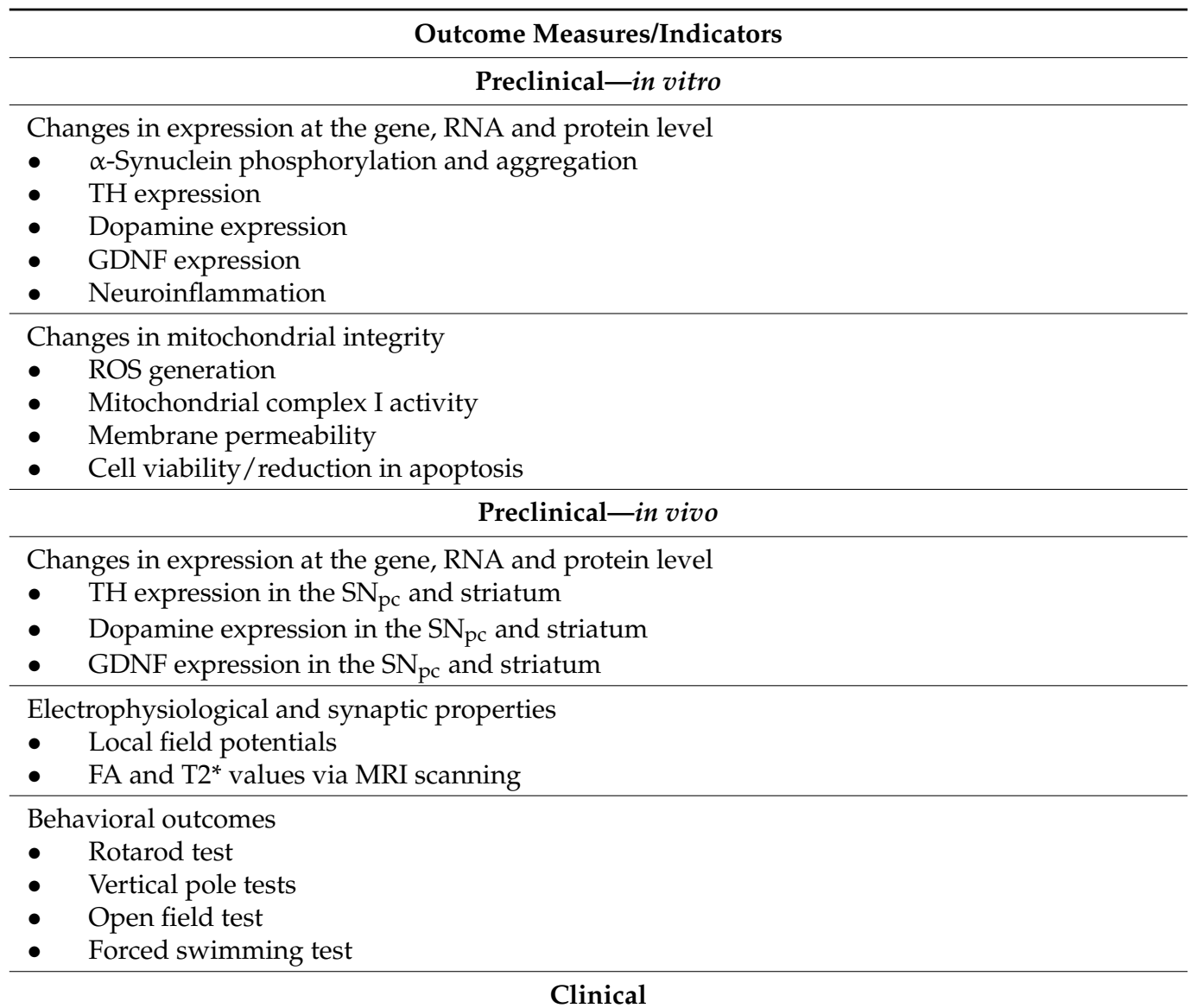

Functional outcomes

- $\quad$ Procedure-related complications/adverse events

- $\quad$ Change in MDS-UPDRS part III motor score

- Change in UDysRS score

- Clinical improvement according to the patients' global impression of change

- Neuropsychological effects assessed by quality-of-life questionnaire

FA = Fractional anisotropy; GDNF = Glial cell line-derived neurotrophic factor; MDS-UPDRS = Movement Disorder Society version of the United Parkinson's Disease Rating Scale; MRI = Magnetic resonance imaging; $\mathrm{PD}=$ Parkinson's disease; $\mathrm{RNA}=$ Ribonucleic acid $; \mathrm{ROS}=$ Reactive oxygen species; $\mathrm{SN}_{\mathrm{pc}}=$ Substantia nigra pars compacta; $\mathrm{STN}$ = Subthalamic nucleus; $\mathrm{TH}=$ Tyrosine hydroxylase; UDysRS = Unified dyskinesia rating scale UPDRS = Unified Parkinson's disease rating scale; US = United States. 
This review additionally identified a current lack of in vitro studies that investigate the mechanistic changes induced by FUS. A significant caveat is that many of the in vivo models that assess the behavioural effects of FUS are confounded by the use of anaesthesia in their experimental design, which is unavoidable due to ethical reasons $[45,46,97]$. Kawaguchi et al. demonstrated that the typically used isoflurane dampens the motor-evoked potentials induced [98]. Of greater significance, several potential mechanisms of how FUS modulates membrane excitability coincide with those of the anaesthetic drugs [80]. As these studies employ the use of anaesthesia, the authors cannot exclude the possibility that the effects of FUS are altered under these conditions due to residual confounders [99]. Therefore, more in vitro studies such as those identified in this scoping review are recommended for more precise characterisation of the cellular mechanisms underpinning FUS. However, current in vitro studies, although captivating, are limited by the use of the PC12 cell culture to model PD. This is a pheochromocytoma cell line and does not exhibit the electrophysiological properties of post-mitotic midbrain dopaminergic neurons (mDANs). One way to circumvent this issue would be through the use of human-induced pluripotent stem cell line-derived mDANs [100], which enables a more accurate recapitulation of sporadic PD pathogenesis in vitro [101].

Chronic stimulation of deep brain structures using low-intensity FUS as a direct replacement for traditional electrode-based DBS removes the invasive procedure required for DBS but would impose the wearing of some form of targeted transducer device. However, given that certain FUS parameters seem to have effects lasting beyond the duration of stimulation, in both in vitro [102], and in in vivo PD models [49], we speculate on the possibility of finding a regular treatment protocol allowing for FUS to be given to the patient, which would induce a long-term therapeutic effect.

It is important to note that whilst the studies we identify specified no damaging effects of FUS, there remains the possibility, as with any neurostimulation tool, of functional adverse events. Whilst more work is therefore required to definitively establish this, it is nonetheless encouraging that, in a recent review of a number of human FUS studies, no evidence of lasting functional side effects or major adverse events was reported [103].

\subsection{Strengths and Limitations}

The findings are derived from a thorough search of three electronic databases. By including results from all study designs (preclinical and clinical), a comprehensive review of research evidence was achieved.

Only 11 studies qualified for inclusion in this review. Conference abstracts and other grey literature were excluded which may entrench publication bias or the 'file-drawer problem' [104]. However, during the screening process, conference abstracts rarely evinced sufficient details that would have been beneficial to this review. Nevertheless, we were still able to collate results in a structured manner and draw conclusions that represent a starting point for more robust future studies. We identified specific gaps in the existing literature, which are outlined in the 'Implications of Findings and Direction of Future Research' Section above.

\section{Conclusions}

This scoping review provides a starting point to better understand the research surrounding FUS in PD around the world. Preclinical evidence indicates that FUS is safe and has beneficial neuromodulatory effects on motor behaviour in PD. However, there is a current lack of mechanistic understanding for these beneficial effects of FUS in PD, either in vivo or in vitro; hence, there is need for further studies with more appropriate cellular models and clear reporting of our suggested outcome measures. FUS seems to have a role in influencing the disease process of PD, and therefore holds great promise as an attractive and powerful neuromodulatory tool for PD. 
Supplementary Materials: The following supporting information can be downloaded at: https: / / www.mdpi.com/article/10.3390/brainsci12020289/s1, Table S1: Search strategies across the four electronic databases as of 13 January 2022, Table S2: Inclusion and exclusion criteria used to assess eligibility of studies.

Author Contributions: Conceptualisation, K.S.L.; methodology, K.S.L., O.C.-L. and D.J.W.; validation, K.S.L., O.C.-L. and D.J.W.; formal analysis, K.S.L.; investigation, K.S.L.; resources, K.S.L., O.C.-L. and D.J.W.; data curation, K.S.L., B.C., T.G.J.S. and A.G; writing-original draft preparation, K.S.L.; writing-review and editing, K.S.L., B.C., T.G.J.S., A.G., O.C.-L. and D.J.W.; visualisation, K.S.L., O.C.-L. and D.J.W.; supervision, O.C.-L. and D.J.W.; project administration, K.S.L., O.C.-L. and D.J.W. All authors have read and agreed to the published version of the manuscript.

Funding: This work was supported in part by grant MR/N0137941/1 for the GW4 BIOMED MRC DTP, awarded to the Universities of Bath, Bristol, Cardiff and Exeter from the Medical Research Council (MRC)/UKRI, and Bristol Research into Alzheimer's and Care for the Elderly (BRACE).

Institutional Review Board Statement: Not applicable.

Informed Consent Statement: Not applicable.

Data Availability Statement: Please find available data in the Supplementary Materials.

Acknowledgments: A special thank you to Kenneth Kek Wee Lee (Papa), Lena Lim (Mama) and Chio Tee Koh (Ahma) back home for their unwavering support and belief in me, without which, I would not be able to achieve my educational goals. Love truly overcomes all obstacles (different time zones and distance).

Conflicts of Interest: The authors declare no conflict of interest.

\section{References}

1. Vila, M.; Jackson-Lewis, V.; Vukosavic, S.; Djaldetti, R.; Liberatore, G.; Offen, D.; Korsmeyer, S.J.; Przedborski, S. Bax ablation prevents dopaminergic neurodegeneration in the 1-methyl- 4-phenyl-1,2,3,6-tetrahydropyridine mouse model of Parkinson's disease. Proc. Natl. Acad. Sci. USA 2001, 98, 2837-2842. [CrossRef] [PubMed]

2. Goetz, C.G.; Tilley, B.C.; Shaftman, S.R.; Stebbins, G.T.; Fahn, S.; Martinez-Martin, P.; Poewe, W.; Sampaio, C.; Stern, M.B.; Dodel, R.; et al. Movement Disorder Society-sponsored revision of the Unified Parkinson's Disease Rating Scale (MDS-UPDRS): Scale presentation and clinimetric testing results. Mov. Disord. 2008, 23, 2129-2170. [CrossRef] [PubMed]

3. Kadastik-Eerme, L.; Rosenthal, M.; Paju, T.; Muldmaa, M.; Taba, P. Health-related quality of life in Parkinson's disease: A cross-sectional study focusing on non-motor symptoms. Health Qual. Life Outcomes 2015, 13, 83. [CrossRef] [PubMed]

4. Carod-Artal, F.J.; Vargas, A.P.; Martinez-Martin, P. Determinants of quality of life in Brazilian patients with Parkinson's disease. Mov. Disord. 2007, 22, 1408-1415. [CrossRef]

5. Hindle, J.V. Ageing, neurodegeneration and Parkinson's disease. Age Ageing 2010, 39, 156-161. [CrossRef]

6. Hirsch, L.; Jette, N.; Frolkis, A.; Steeves, T.; Pringsheim, T. The Incidence of Parkinson's Disease: A Systematic Review and Meta-Analysis. Neuroepidemiology 2016, 46, 292-300. [CrossRef]

7. Pringsheim, T.; Jette, N.; Frolkis, A.; Steeves, T.D. The prevalence of Parkinson's disease: A systematic review and meta-analysis. Mov. Disord. 2014, 29, 1583-1590. [CrossRef]

8. Yang, W.; Hamilton, J.L.; Kopil, C.; Beck, J.C.; Tanner, C.M.; Albin, R.L.; Ray Dorsey, E.; Dahodwala, N.; Cintina, I.; Hogan, P.; et al. Current and projected future economic burden of Parkinson's disease in the U.S. NPJ Parkinson's Dis. 2020, 6, 15. [CrossRef]

9. Lozano, A.M.; Lipsman, N. Probing and regulating dysfunctional circuits using deep brain stimulation. Neuron 2013, 77, 406-424. [CrossRef]

10. Lozano, A.M.; Lipsman, N.; Bergman, H.; Brown, P.; Chabardes, S.; Chang, J.W.; Matthews, K.; McIntyre, C.C.; Schlaepfer, T.E.; Schulder, M.; et al. Deep brain stimulation: Current challenges and future directions. Nat. Rev. Neurol. 2019, 15, 148-160. [CrossRef]

11. McIntyre, C.C.; Anderson, R.W. Deep brain stimulation mechanisms: The control of network activity via neurochemistry modulation. J. Neurochem. 2016, 139 (Suppl. S1), 338-345. [CrossRef] [PubMed]

12. Xie, C.L.; Shao, B.; Chen, J.; Zhou, Y.; Lin, S.Y.; Wang, W.W. Effects of neurostimulation for advanced Parkinson's disease patients on motor symptoms: A multiple-treatments meta-analysas of randomized controlled trials. Sci. Rep. 2016, 6, 25285. [CrossRef] [PubMed]

13. St George, R.J.; Nutt, J.G.; Burchiel, K.J.; Horak, F.B. A meta-regression of the long-term effects of deep brain stimulation on balance and gait in PD. Neurology 2010, 75, 1292-1299. [CrossRef]

14. Williams, A.; Gill, S.; Varma, T.; Jenkinson, C.; Quinn, N.; Mitchell, R.; Scott, R.; Ives, N.; Rick, C.; Daniels, J.; et al. Deep brain stimulation plus best medical therapy versus best medical therapy alone for advanced Parkinson's disease (PD SURG trial): A randomised, open-label trial. Lancet Neurol. 2010, 9, 581-591. [CrossRef] 
15. Weaver, F.M.; Follett, K.; Stern, M.; Hur, K.; Harris, C.; Marks, W.J.; Rothlind, J.; Sagher, O.; Reda, D.; Moy, C.S.; et al. Bilateral deep brain stimulation vs best medical therapy for patients with advanced Parkinson disease: A randomized controlled trial. JAMA 2009, 301, 63-73. [CrossRef] [PubMed]

16. Zrinzo, L.; Foltynie, T.; Limousin, P.; Hariz, M.I. Reducing hemorrhagic complications in functional neurosurgery: A large case series and systematic literature review. J. Neurosurg. 2012, 116, 84-94. [CrossRef]

17. Xiaowu, H.; Xiufeng, J.; Xiaoping, Z.; Bin, H.; Laixing, W.; Yiqun, C.; Jinchuan, L.; Aiguo, J.; Jianmin, L. Risks of intracranial hemorrhage in patients with Parkinson's disease receiving deep brain stimulation and ablation. Parkinsonism Relat. Disord. 2010, 16, 96-100. [CrossRef]

18. Jitkritsadakul, O.; Bhidayasiri, R.; Kalia, S.K.; Hodaie, M.; Lozano, A.M.; Fasano, A. Systematic review of hardware-related complications of Deep Brain Stimulation: Do new indications pose an increased risk? Brain Stimul. 2017, 10, 967-976. [CrossRef]

19. Friehs, G.M.; Park, M.C.; Goldman, M.A.; Zerris, V.A.; Norén, G.; Sampath, P. Stereotactic radiosurgery for functional disorders. Neurosurg. Focus 2007, 23, E3. [CrossRef]

20. Eisenberg, H.M.; Krishna, V.; Elias, W.J.; Cosgrove, G.R.; Gandhi, D.; Aldrich, C.E.; Fishman, P.S. MR-guided focused ultrasound pallidotomy for Parkinson's disease: Safety and feasibility. J. Neurosurg. 2020, 135, 792-798. [CrossRef]

21. Martínez-Fernández, R.; Máñez-Miró, J.U.; Rodríguez-Rojas, R.; Del Álamo, M.; Shah, B.B.; Hernández-Fernández, F.; PinedaPardo, J.A.; Monje, M.H.G.; Fernández-Rodríguez, B.; Sperling, S.A.; et al. Randomized Trial of Focused Ultrasound Subthalamotomy for Parkinson's Disease. N. Engl. J. Med. 2020, 383, 2501-2513. [CrossRef] [PubMed]

22. Jung, N.Y.; Park, C.K.; Kim, M.; Lee, P.H.; Sohn, Y.H.; Chang, J.W. The efficacy and limits of magnetic resonance-guided focused ultrasound pallidotomy for Parkinson's disease: A Phase I clinical trial. J. Neurosurg. 2018, 130, 1853-1861. [CrossRef] [PubMed]

23. ClinicalTrials.gov. Safety and Initial Effectiveness of Transcranial MR Guided Focused Ultrasound for the Treatment of Parkinson's Disease (TDPD). Available online: https: / clinicaltrials.gov/ct2/show / NCT04002596 (accessed on 31 May 2021).

24. ClinicalTrials.gov. Parkinson's Disease (PD) Treated with Focused Ultrasound Subthalamotomy at an Early Stage (EarlyFocus). Available online: https:/ / clinicaltrials.gov/ct2/show /NCT04692116 (accessed on 31 May 2021).

25. Cho, S.S.; Strafella, A.P. rTMS of the left dorsolateral prefrontal cortex modulates dopamine release in the ipsilateral anterior cingulate cortex and orbitofrontal cortex. PLoS ONE 2009, 4, e6725. [CrossRef]

26. Brys, M.; Fox, M.D.; Agarwal, S.; Biagioni, M.; Dacpano, G.; Kumar, P.; Pirraglia, E.; Chen, R.; Wu, A.; Fernandez, H.; et al. Multifocal repetitive TMS for motor and mood symptoms of Parkinson disease: A randomized trial. Neurology 2016, 87, 1907-1915. [CrossRef]

27. Ba, M.; Kong, M.; Guan, L.; Yi, M.; Zhang, H. Repetitive transcranial magnetic stimulation (rTMS) improves behavioral and biochemical deficits in levodopa-induced dyskinetic rats model. Oncotarget 2016, 7, 58802-58812. [CrossRef] [PubMed]

28. Lefaucheur, J.P.; Antal, A.; Ayache, S.S.; Benninger, D.H.; Brunelin, J.; Cogiamanian, F.; Cotelli, M.; De Ridder, D.; Ferrucci, R.; Langguth, B.; et al. Evidence-based guidelines on the therapeutic use of transcranial direct current stimulation (tDCS). Clin. Neurophysiol. 2017, 128, 56-92. [CrossRef]

29. Fini, M.; Tyler, W.J. Transcranial focused ultrasound: A new tool for non-invasive neuromodulation. Int. Rev. Psychiatry 2017, 29, 168-177. [CrossRef]

30. Goetz, S.M.; Deng, Z.D. The development and modelling of devices and paradigms for transcranial magnetic stimulation. Int. Rev. Psychiatry 2017, 29, 115-145. [CrossRef]

31. Bonmassar, G.; Lee, S.W.; Freeman, D.K.; Polasek, M.; Fried, S.I.; Gale, J.T. Microscopic magnetic stimulation of neural tissue. Nat. Commun. 2012, 3, 921. [CrossRef]

32. O’Brien, W.D. Ultrasound-biophysics mechanisms. Prog. Biophys. Mol. Biol. 2007, 93, 212-255. [CrossRef]

33. Mueller, J.; Legon, W.; Opitz, A.; Sato, T.F.; Tyler, W.J. Transcranial focused ultrasound modulates intrinsic and evoked EEG dynamics. Brain Stimul. 2014, 7, 900-908. [CrossRef] [PubMed]

34. Legon, W.; Sato, T.F.; Opitz, A.; Mueller, J.; Barbour, A.; Williams, A.; Tyler, W.J. Transcranial focused ultrasound modulates the activity of primary somatosensory cortex in humans. Nat. Neurosci. 2014, 17, 322-329. [CrossRef] [PubMed]

35. Munn, Z.; Peters, M.D.J.; Stern, C.; Tufanaru, C.; McArthur, A.; Aromataris, E. Systematic review or scoping review? Guidance for authors when choosing between a systematic or scoping review approach. BMC Med. Res. Methodol. 2018, 18, 143. [CrossRef] [PubMed]

36. Tricco, A.C.; Lillie, E.; Zarin, W.; O’Brien, K.K.; Colquhoun, H.; Levac, D.; Moher, D.; Peters, M.D.J.; Horsley, T.; Weeks, L.; et al. PRISMA Extension for Scoping Reviews (PRISMA-ScR): Checklist and Explanation. Ann. Intern. Med. 2018, 169, 467-473. [CrossRef] [PubMed]

37. Lee, K.S.; Zhang, J.J.Y.; Nga, V.D.W.; Ng, C.H.; Tai, B.C.; Higgins, J.; Syn, N. Tenets for the Proper Conduct and Use of Meta-Analyses: A Practical Guide for Neurosurgeons. World Neurosurg. 2022, in press.

38. Lee, K.S.; Zhang, J.J.Y.; Alamri, A.; Chari, A. Neurosurgery Education in the Medical School Curriculum: A Scoping Review. World Neurosurg. 2020, 144, e631-e642. [CrossRef]

39. Cohen, J. A coefficient of agreement for nominal scales. Educ. Psychol. Meas. 1960, 20, 37-47. [CrossRef]

40. Chen, X.; Wang, D.; Zhang, L.; Yao, H.; Zhu, H.; Zhao, N.; Peng, X.; Yang, K. Neuroprotective Effect of Low-Intensity Pulsed Ultrasound on the Mouse MPTP/MPP. Ultrasound Med. Biol. 2021, 47, 2321-2330. [CrossRef] 
41. Dong, Y.; Liu, D.; Zhao, Y.; Yuan, Y.; Wang, W.; Wu, S.; Liang, X.; Wang, Z.; Liu, L. Assessment of Neuroprotective Effects of Low-Intensity Transcranial Ultrasound Stimulation in a Parkinson's Disease Rat Model by Fractional Anisotropy and Relaxation Time T2. Front. Neurosci. 2021, 15, 590354. [CrossRef] [PubMed]

42. Karmacharya, M.B.; Hada, B.; Park, S.R.; Choi, B.H. Low-Intensity Ultrasound Decreases $\alpha$-Synuclein Aggregation via Attenuation of Mitochondrial Reactive Oxygen Species in MPP(+)-Treated PC12 Cells. Mol. Neurobiol. 2017, 54, 6235-6244. [CrossRef]

43. Sung, C.Y.; Chiang, P.K.; Tsai, C.W.; Yang, F.Y. Low-Intensity Pulsed Ultrasound Enhances Neurotrophic Factors and Alleviates Neuroinflammation in a Rat Model of Parkinson's Disease. Cereb. Cortex 2021. [CrossRef] [PubMed]

44. Tarnaud, T.; Joseph, W.; Martens, L.; Tanghe, E. Computational Modeling of Ultrasonic Subthalamic Nucleus Stimulation. IEEE Trans. Biomed. Eng. 2019, 66, 1155-1164. [CrossRef]

45. Wang, Z.; Yan, J.; Wang, X.; Yuan, Y.; Li, X. Transcranial Ultrasound Stimulation Directly Influences the Cortical Excitability of the Motor Cortex in Parkinsonian Mice. Mov. Disord. 2020, 35, 693-698. [CrossRef] [PubMed]

46. Xu, T.; Lu, X.; Peng, D.; Wang, G.; Chen, C.; Liu, W.; Wu, W.; Mason, T.J. Ultrasonic stimulation of the brain to enhance the release of dopamine-A potential novel treatment for Parkinson's disease. Ultrason. Sonochem. 2020, 63, 104955. [CrossRef]

47. Yuan, Y.; Zhao, Z.; Wang, Z.; Wang, X.; Yan, J.; Li, X. The Effect of Low-Intensity Transcranial Ultrasound Stimulation on Behavior in a Mouse Model of Parkinson's Disease Induced by MPTP. IEEE Trans. Neural Syst. Rehabil. Eng. 2020, 28, 1017-1021. [CrossRef] [PubMed]

48. Zhao, L.; Feng, Y.; Shi, A.; Zhang, L.; Guo, S.; Wan, M. Neuroprotective Effect of Low-Intensity Pulsed Ultrasound against MPP. Ultrasound Med. Biol. 2017, 43, 1986-1999. [CrossRef] [PubMed]

49. Zhou, H.; Niu, L.; Meng, L.; Lin, Z.; Zou, J.; Xia, X.; Huang, X.; Zhou, W.; Bian, T.; Zheng, H. Noninvasive Ultrasound Deep Brain Stimulation for the Treatment of Parkinson's Disease Model Mouse. Research 2019, 2019, 1748489. [CrossRef]

50. Zhou, H.; Niu, L.; Xia, X.; Lin, Z.; Liu, X.; Su, M.; Guo, R.; Meng, L.; Zheng, H. Wearable Ultrasound Improves Motor Function in an MPTP Mouse Model of Parkinson's Disease. IEEE Trans. Biomed. Eng. 2019, 66, 3006-3013. [CrossRef] [PubMed]

51. Gross, A.; McDonnell, J.M.; Korsmeyer, S.J. BCL-2 family members and the mitochondria in apoptosis. Genes Dev. 1999, 13, 1899-1911. [CrossRef]

52. Cory, S.; Adams, J.M. The Bcl2 family: Regulators of the cellular life-or-death switch. Nat. Rev. Cancer 2002, 2, 647-656. [CrossRef]

53. Sas, K.; Robotka, H.; Toldi, J.; Vécsei, L. Mitochondria, metabolic disturbances, oxidative stress and the kynurenine system, with focus on neurodegenerative disorders. J. Neurol. Sci. 2007, 257, 221-239. [CrossRef] [PubMed]

54. Rekha, K.R.; Selvakumar, G.P. Gene expression regulation of $\mathrm{Bcl} 2$, Bax and cytochrome-C by geraniol on chronic MPTP/probenecid induced C57BL/ 6 mice model of Parkinson's disease. Chem. Biol. Interact. 2014, 217, 57-66. [CrossRef]

55. Robinson, E.J.; Aguiar, S.P.; Kouwenhoven, W.M.; Starmans, D.S.; von Oerthel, L.; Smidt, M.P.; van der Heide, L.P. Survival of midbrain dopamine neurons depends on the Bcl2 factor Mcl1. Cell Death Discov. 2018, 4, 107. [CrossRef] [PubMed]

56. Kluck, R.M.; Bossy-Wetzel, E.; Green, D.R.; Newmeyer, D.D. The release of cytochrome c from mitochondria: A primary site for Bcl-2 regulation of apoptosis. Science 1997, 275, 1132-1136. [CrossRef] [PubMed]

57. Castro-Caldas, M.; Carvalho, A.N.; Rodrigues, E.; Henderson, C.J.; Wolf, C.R.; Rodrigues, C.M.; Gama, M.J. Tauroursodeoxycholic acid prevents MPTP-induced dopaminergic cell death in a mouse model of Parkinson's disease. Mol. Neurobiol. 2012, 46, 475-486. [CrossRef]

58. Choi, S.; Oh, J.Y.; Kim, S.J. Ginsenoside Rh2 induces Bcl-2 family proteins-mediated apoptosis in vitro and in xenografts in vivo models. J. Cell Biochem. 2011, 112, 330-340. [CrossRef] [PubMed]

59. Offen, D.; Beart, P.M.; Cheung, N.S.; Pascoe, C.J.; Hochman, A.; Gorodin, S.; Melamed, E.; Bernard, R.; Bernard, O. Transgenic mice expressing human Bcl-2 in their neurons are resistant to 6-hydroxydopamine and 1-methyl-4-phenyl-1,2,3,6- tetrahydropyridine neurotoxicity. Proc. Natl. Acad. Sci. USA 1998, 95, 5789-5794. [CrossRef] [PubMed]

60. Yang, L.; Matthews, R.T.; Schulz, J.B.; Klockgether, T.; Liao, A.W.; Martinou, J.C.; Penney, J.B.; Hyman, B.T.; Beal, M.F. 1-Methyl4-phenyl-1,2,3,6-tetrahydropyride neurotoxicity is attenuated in mice overexpressing Bcl-2. J. Neurosci. 1998, 18, 8145-8152. [CrossRef]

61. Okochi, M.; Walter, J.; Koyama, A.; Nakajo, S.; Baba, M.; Iwatsubo, T.; Meijer, L.; Kahle, P.J.; Haass, C. Constitutive phosphorylation of the Parkinson's disease associated alpha-synuclein. J. Biol. Chem. 2000, 275, 390-397. [CrossRef]

62. Simón-Sánchez, J.; Schulte, C.; Bras, J.M.; Sharma, M.; Gibbs, J.R.; Berg, D.; Paisan-Ruiz, C.; Lichtner, P.; Scholz, S.W.; Hernandez, D.G.; et al. Genome-wide association study reveals genetic risk underlying Parkinson's disease. Nat. Genet. 2009, 41, 1308-1312. [CrossRef]

63. Devine, M.J.; Ryten, M.; Vodicka, P.; Thomson, A.J.; Burdon, T.; Houlden, H.; Cavaleri, F.; Nagano, M.; Drummond, N.J.; Taanman, J.W.; et al. Parkinson's disease induced pluripotent stem cells with triplication of the $\alpha$-synuclein locus. Nat. Commun. 2011, 2, 440. [CrossRef]

64. Lin, L.F.; Doherty, D.H.; Lile, J.D.; Bektesh, S.; Collins, F. GDNF: A glial cell line-derived neurotrophic factor for midbrain dopaminergic neurons. Science 1993, 260, 1130-1132. [CrossRef]

65. Fan, C.H.; Ting, C.Y.; Lin, C.Y.; Chan, H.L.; Chang, Y.C.; Chen, Y.Y.; Liu, H.L.; Yeh, C.K. Noninvasive, Targeted, and Non-Viral Ultrasound-Mediated GDNF-Plasmid Delivery for Treatment of Parkinson's Disease. Sci. Rep. 2016, 6, 19579. [CrossRef] [PubMed] 
66. Pouliopoulos, A.N.; Kwon, N.; Jensen, G.; Meaney, A.; Niimi, Y.; Burgess, M.T.; Ji, R.; McLuckie, A.J.; Munoz, F.A.; Kamimura, H.A.S.; et al. Safety evaluation of a clinical focused ultrasound system for neuronavigation guided blood-brain barrier opening in non-human primates. Sci. Rep. 2021, 11, 15043. [CrossRef] [PubMed]

67. Chen, K.T.; Wei, K.C.; Liu, H.L. Theranostic Strategy of Focused Ultrasound Induced Blood-Brain Barrier Opening for CNS Disease Treatment. Front. Pharmacol. 2019, 10, 86. [CrossRef]

68. Carpentier, A.; Canney, M.; Vignot, A.; Reina, V.; Beccaria, K.; Horodyckid, C.; Karachi, C.; Leclercq, D.; Lafon, C.; Chapelon, J.Y.; et al. Clinical trial of blood-brain barrier disruption by pulsed ultrasound. Sci. Transl. Med. 2016, 8, 343re342. [CrossRef]

69. Fedak, K.M.; Bernal, A.; Capshaw, Z.A.; Gross, S. Applying the Bradford Hill criteria in the 21st century: How data integration has changed causal inference in molecular epidemiology. Emerg. Themes. Epidemiol. 2015, 12, 14. [CrossRef] [PubMed]

70. Tyler, W.J.; Tufail, Y.; Finsterwald, M.; Tauchmann, M.L.; Olson, E.J.; Majestic, C. Remote excitation of neuronal circuits using low-intensity, low-frequency ultrasound. PLOS ONE 2008, 3, e3511. [CrossRef]

71. Tufail, Y.; Yoshihiro, A.; Pati, S.; Li, M.M.; Tyler, W.J. Ultrasonic neuromodulation by brain stimulation with transcranial ultrasound. Nat. Protoc. 2011, 6, 1453-1470. [CrossRef]

72. Kubanek, J.; Shukla, P.; Das, A.; Baccus, S.A.; Goodman, M.B. Ultrasound Elicits Behavioral Responses through Mechanical Effects on Neurons and Ion Channels in a Simple Nervous System. J. Neurosci. 2018, 38, 3081-3091. [CrossRef]

73. Tufail, Y.; Matyushov, A.; Baldwin, N.; Tauchmann, M.L.; Georges, J.; Yoshihiro, A.; Tillery, S.I.; Tyler, W.J. Transcranial pulsed ultrasound stimulates intact brain circuits. Neuron 2010, 66, 681-694. [CrossRef]

74. Kamimura, H.A.; Wang, S.; Chen, H.; Wang, Q.; Aurup, C.; Acosta, C.; Carneiro, A.A.; Konofagou, E.E. Focused ultrasound neuromodulation of cortical and subcortical brain structures using $1.9 \mathrm{MHz}$. Med. Phys. 2016, 43, 5730. [CrossRef]

75. Pouget, P.; Frey, S.; Ahnine, H.; Attali, D.; Claron, J.; Constans, C.; Aubry, J.F.; Arcizet, F. Neuronavigated Repetitive Transcranial Ultrasound Stimulation Induces Long-Lasting and Reversible Effects on Oculomotor Performance in Non-human Primates. Front. Physiol. 2020, 11, 1042. [CrossRef] [PubMed]

76. Yoo, S.; Mittelstein, D.R.; Hurt, R.; Lacroix, J.; Shapiro, M.G. Focused ultrasound excites neurons via mechanosensitive calcium accumulation and ion channel amplification. Nat Commun 2022, 13, 493. [CrossRef] [PubMed]

77. Krasovitski, B.; Frenkel, V.; Shoham, S.; Kimmel, E. Intramembrane cavitation as a unifying mechanism for ultrasound-induced bioeffects. Proc. Natl. Acad. Sci. USA 2011, 108, 3258-3263. [CrossRef] [PubMed]

78. Yoo, S.S.; Bystritsky, A.; Lee, J.H.; Zhang, Y.; Fischer, K.; Min, B.K.; McDannold, N.J.; Pascual-Leone, A.; Jolesz, F.A. Focused ultrasound modulates region-specific brain activity. Neuroimage 2011, 56, 1267-1275. [CrossRef]

79. Kubanek, J. Neuromodulation with transcranial focused ultrasound. Neurosurg. Focus 2018, 44, E14. [CrossRef]

80. Jerusalem, A.; Al-Rekabi, Z.; Chen, H.; Ercole, A.; Malboubi, M.; Tamayo-Elizalde, M.; Verhagen, L.; Contera, S. Electrophysiological-mechanical coupling in the neuronal membrane and its role in ultrasound neuromodulation and general anaesthesia. Acta Biomater. 2019, 97, 116-140. [CrossRef]

81. Prieto, M.L.; Ömer, O.; Khuri-Yakub, B.T.; Maduke, M.C. Dynamic response of model lipid membranes to ultrasonic radiation force. PLoS ONE 2013, 8, e77115. [CrossRef]

82. Renzhiglova, E.; Ivantsiv, V.; Xu, Y. Difference frequency magneto-acousto-electrical tomography (DF-MAET): Application of ultrasound-induced radiation force to imaging electrical current density. IEEE Trans. Ultrason. Ferroelectr. Freq. Control 2010, 57, 2391-2402. [CrossRef]

83. Kubanek, J.; Shi, J.; Marsh, J.; Chen, D.; Deng, C.; Cui, J. Ultrasound modulates ion channel currents. Sci. Rep. 2016, 6, 24170. [CrossRef] [PubMed]

84. Prieto, M.L.; Firouzi, K.; Khuri-Yakub, B.T.; Maduke, M. Activation of Piezo1 but Not Na. Ultrasound Med. Biol. 2018, 44, 1217-1232. [CrossRef] [PubMed]

85. Wang, F.; Shi, Y.; Lu, L.; Liu, L.; Cai, Y.; Zheng, H.; Liu, X.; Yan, F.; Zou, C.; Sun, C.; et al. Targeted delivery of GDNF through the blood-brain barrier by MRI-guided focused ultrasound. PLoS ONE 2012, 7, e52925. [CrossRef] [PubMed]

86. Huang, Q.; Deng, J.; Wang, F.; Chen, S.; Liu, Y.; Wang, Z.; Cheng, Y. Targeted gene delivery to the mouse brain by MRI-guided focused ultrasound-induced blood-brain barrier disruption. Exp. Neurol. 2012, 233, 350-356. [CrossRef]

87. Allen, N.J.; Barres, B.A. Neuroscience: Glia-More than just brain glue. Nature 2009, 457, 675-677. [CrossRef]

88. De Luca, C.; Colangelo, A.M.; Virtuoso, A.; Alberghina, L.; Papa, M. Neurons, Glia, Extracellular Matrix and Neurovascular Unit: A Systems Biology Approach to the Complexity of Synaptic Plasticity in Health and Disease. Int. J. Mol. Sci. 2020, 21, 1539. [CrossRef]

89. Grosche, J.; Matyash, V.; Möller, T.; Verkhratsky, A.; Reichenbach, A.; Kettenmann, H. Microdomains for neuron-glia interaction: Parallel fiber signaling to Bergmann glial cells. Nat. Neurosci. 1999, 2, 139-143. [CrossRef]

90. Tremblay, M.E.; Cookson, M.R.; Civiero, L. Glial phagocytic clearance in Parkinson's disease. Mol. Neurodegener. 2019, 14, 16. [CrossRef]

91. Oh, S.J.; Lee, J.M.; Kim, H.B.; Lee, J.; Han, S.; Bae, J.Y.; Hong, G.S.; Koh, W.; Kwon, J.; Hwang, E.S.; et al. Ultrasonic Neuromodulation via Astrocytic TRPA1. Curr. Biol. 2020, 30, 948. [CrossRef]

92. Lee, C.J.; Mannaioni, G.; Yuan, H.; Woo, D.H.; Gingrich, M.B.; Traynelis, S.F. Astrocytic control of synaptic NMDA receptors. J. Physiol. 2007, 581, 1057-1081. [CrossRef]

93. Clasadonte, J.; Dong, J.; Hines, D.J.; Haydon, P.G. Astrocyte control of synaptic NMDA receptors contributes to the progressive development of temporal lobe epilepsy. Proc. Natl. Acad. Sci. USA 2013, 110, 17540-17545. [CrossRef] 
94. Blackmore, D.G.; Turpin, F.; Palliyaguru, T.; Evans, H.T.; Chicoteau, A.; Lee, W.; Pelekanos, M.; Nguyen, N.; Song, J.; Sullivan, R.K.P.; et al. Low-intensity ultrasound restores long-term potentiation and memory in senescent mice through pleiotropic mechanisms including NMDAR signaling. Mol. Psychiatry 2021. [CrossRef]

95. Lee, K.S.; Young, A.; King, H.; Jenkins, A.T.A.; Davies, A. Variation in Definitions of Burn Wound Infection Limits the Validity of Systematic Review Findings in Burn Care: A Systematic Review of Reviews. Burns 2021, in press. [CrossRef] [PubMed]

96. Björklund, A.; Cenci-Nilsson, A. Recent Advances in Parkinson's Disease; Elsevier: Amsterdam, The Netherlands, 2020 ; Volume 252.

97. Folloni, D.; Verhagen, L.; Mars, R.B.; Fouragnan, E.; Constans, C.; Aubry, J.F.; Rushworth, M.F.S.; Sallet, J. Manipulation of Subcortical and Deep Cortical Activity in the Primate Brain Using Transcranial Focused Ultrasound Stimulation. Neuron 2019, 101, 1109-1116. [CrossRef]

98. Kawaguchi, M.; Shimizu, K.; Furuya, H.; Sakamoto, T.; Ohnishi, H.; Karasawa, J. Effect of isoflurane on motor-evoked potentials induced by direct electrical stimulation of the exposed motor cortex with single, double, and triple stimuli in rats. Anesthesiology 1996, 85, 1176-1183. [CrossRef] [PubMed]

99. Han, S.; Kim, M.; Kim, H.; Shin, H.; Youn, I. Ketamine Inhibits Ultrasound Stimulation-Induced Neuromodulation by Blocking Cortical Neuron Activity. Ultrasound Med. Biol. 2018, 44, 635-646. [CrossRef]

100. Takahashi, K.; Yamanaka, S. Induction of pluripotent stem cells from mouse embryonic and adult fibroblast cultures by defined factors. Cell 2006, 126, 663-676. [CrossRef] [PubMed]

101. Soldner, F.; Hockemeyer, D.; Beard, C.; Gao, Q.; Bell, G.W.; Cook, E.G.; Hargus, G.; Blak, A.; Cooper, O.; Mitalipova, M.; et al. Parkinson's disease patient-derived induced pluripotent stem cells free of viral reprogramming factors. Cell 2009, 136, 964-977. [CrossRef]

102. Clennell, B.; Steward, T.G.J.; Elley, M.; Shin, E.; Weston, M.; Drinkwater, B.W.; Whitcomb, D.J. Transient ultrasound stimulation has lasting effects on neuronal excitability. Brain Stimul. 2021, 14, 217-225. [CrossRef]

103. Legon, W.; Adams, S.; Bansal, P.; Patel, P.D.; Hobbs, L.; Ai, L.; Mueller, J.K.; Meekins, G.; Gillick, B.T. A retrospective qualitative report of symptoms and safety from transcranial focused ultrasound for neuromodulation in humans. Sci. Rep. 2020, 10, 5573. [CrossRef]

104. Simonsohn, U.; Nelson, L.D.; Simmons, J.P. P-curve: A key to the file-drawer. J. Exp. Psychol. Gen. 2014, 143, 534-547. [CrossRef] [PubMed] 